\title{
Prognostic Value of Biochemical and Hematological Parameters in Children with Nephrotic Syndrome
}

\author{
Roy $\mathrm{RR}^{1}$, Islam $\mathrm{MR}^{2}$, Jesmin $\mathrm{T}^{3}$, Matin $\mathrm{A}^{4}$, Islam $\mathrm{MR}^{5}$
}

\begin{abstract}
Background: Nephrotic syndrome causes a great morbidity and mortality among the children. Objective: The purpose of the present study was to compare the biochemical and hematological parameters and their prognostic value in steroid resistant (SRNS), frequent relapse and steroid dependent (FRNS+SDNS) and infrequent relapse (IFRNS) groups. Methodology: A prospective study of 43 children with idiopathic nephrotic syndrome (INS) selected randomly out of 480 children admitted with the disease at Bangabandhu Sheikh Mujib Medical University (BSMMU), Dhaka from January 2003 to January 2005. There were 24 steroid sensitive nephrotic syndrome (SSNS) and 19 steroid resistant nephrotic syndrome (SRNS), of SSNS group 13 were infrequent relapse (IFRNS) and 11 were frequent relapse steroid dependent (FRNS+SDNS). Result: SRNS has low serum total protein (STP), albumin and hemoglobin compared to $\mathrm{SSNS}$ ( $\mathrm{P}<0.01$, $\mathrm{P}<0.001)$. SRNS also has high cholesterol, creatinine and urinary total protein (UTP) than $\mathrm{SSNS}(\mathrm{P}<0.01$, $\mathrm{P}<0.001)$. Higher difference was observed between SRNS and IFRNS $(\mathrm{P}<0.001)$. High serum cholesterol, UTP and low hemoglobin were found in FRNS+SDNS compared to IFRNS $(\mathrm{P}<0.01, \mathrm{P}<0.05)$. Conclusion: STP, albumin, creatinine were equally low in SRNS and FRNS+SDNS. [J Shaheed Suhrawardy Med Coll, 2013;5(2):95-98]
\end{abstract}

Keywords: Biochemical parameters, hematological parameters, nephrotic syndrome

Received: July 2013; Revised: August 2013; Accepted: September 2013

\section{Introduction}

Nephrotic syndrome is characterized by massive proteinuria (urinary total protein $>1 \mathrm{gm} / \mathrm{m} 2 /$ day or urinary spot protein creatinine ratio of $>200 \mathrm{mg} / \mathrm{mmol}$ ), Hypoalbuminemia (serum albumin $<2.5 \mathrm{gm} / \mathrm{dl}$ ), edema and hypercholesterolemia (serum cholesterol $>250 \mathrm{mg} / \mathrm{dl})^{1}$. Clinical and biochemical features of nephrotic syndrome result from heavy proteinuria with consequent hypoalbuminemia and edema ${ }^{2}$.

Estimate of annual incidence of nephrotic syndrome is 2-7 per 100,000 children and the prevalence is $12-16$ per 100,000 children. There is epidemiological evidence of higher incidence of nephrotic syndrome of children from South Asia and Africa ${ }^{2-5}$. Primary or idiopathic nephrotic syndrome is commonly seen in $95 \%$ of patients ${ }^{6}, 80 \%$ of whom show histological features of minimal change nephrotic syndrome (MCNS) and have good prognosis ${ }^{7-8}$. Although recurrence is common in nephrotic syndrome, 90$95 \%$ of children with MCNS are responsive to steroid therapy with complete clinical and biochemical remission and have excellent long term prognosis ${ }^{2,6,7,9}$. Steroid sensitive nephrotic syndrome (SSNS) comprises $80-90 \%$ of nephrotic syndrome and rest $10-20 \%$ nephrotic syndrome is steroid resistant $(\mathrm{SRNS})^{10}$. Hypertension, hematuria,

1. Dr. Ranjit Ranjan Roy, Associate Professor, Department of Pediatric Nephrology, Bangabandhu Sheikh Mujib Medical University, Dhaka

2. Dr. Md. Rafiqul Islam, Associate Professor, Department of Pediatrics, Shaheed Shuhrawardy Medical College, Dhaka

3. Dr. Tahmina Jesmin, Resident Phase B, Department of Pediatric Nephrology, Bangabandhu Sheikh Mujib Medical University, Dhaka

4. Dr. Abdul Matin, Assistant Professor, Department of Pediatrics, Shaheed Shuhrawardy Medical College, Dhaka

5. Dr. Md. Reazul Islam, Medical officer, Dhaka National Medical Institute \& Hospital, Dhaka

\section{Correspondence}

Dr. Md. Rafiqul Islam, Associate Professor, Department of Paediatrics, Shaheed Shurawardy Medical College \& Hospital, Sher-E-Bangla Nagar, Dhaka, Bangladesh; Email : rafiq.1956@yahoo.com; Cell No : +8801715067652

Conflict of interest: Auttors have declared no conflict of inferest.

Financial Support: None

Contributions by authors: RRR, MRI \& TJ involved-from protocol preparation to manuscriptive writing; TJ,AM, MRI contributed in-data analysis and preparation of manuscript as well as revised the manuscript. 
anemia, persistent hypocomplementimia with persistent raised serum creatinine and high cholesterol, unfavorable age $(<2$ years and $>8$ years) are regarded as bad prognostic features ${ }^{1,2,7,10}$. So, it is importancte to correlate the biochemical and hematological parameters with the prognosis of the disease.

The objectives of the study were to compare the biochemical and hematological parameters and their prognostic value in steroid resistant (SRNS), frequent relapse and steroid dependent (FRNS+SDNS) and infrequent relapse (IFRNS) groups.

\section{Methodology}

This observational prospective study was carried out in the pediatric nephrology unit of the Department of Pediatrics of Bangabandhu Sheikh Mujib Medical University (BSMMU), Dhaka, Bangladesh from January, 2003 to January, 2005. The hospital is a tertiary referral hospital with diagnostic and treatment facilities. A total of 480 children with primary nephrotic syndrome were admitted in BSMMU during the study period. Forty three (43) children were randomly selected who were aged 1-15 years. Among them 19 had steroid resistant nephrotic syndrome (SRNS) labeled as Group-B and 24 were steroid sensitive nephrotic syndrome (SSNS) and was labeled as Group A, in SSNS 11 children had FRNS+SDNS (Group A1) and 13 had IFRNS syndrome in Group A2. Among 19 children with SRNS, the histological reports on biopsy were mesangial proliferative glomerulonephritis (7 children), MCNS (3 children) focal segmental glomerulosclerosis (5 children), membrano proliferative glomerulonephritis (2 children), and membranous glomerulonephritis (2 children). Higher number of SRNS was due to tertiary referral nature of the hospital. Children below one year and above fifteen years and those with congenital nephrotic syndrome, nephrotic syndrome secondary to systematic disease like systematic lupus erythematosis, hepatitis B, Henoch Schonlein purpura, falciparum malaria, lymphoma and amylodosis were excluded from the study. Those with severe protein energy malnutrition or Down's syndrome were also excluded. Parents and guardians of the enrolled children were informed about the purpose and procedure of the study and written consent was obtained at the enrollment. They were given the choice to withdraw from the study at any point of time during the course of study. Data was collected by pre-tested semi structured questionnaire. The study was approved by Ethical Review Committee of BSMMU.

Laboratory Investigations: Urinary Total Protein (UTP) was measured by auto analyzer (RA 50 chemistry analyzer). Five $\mathrm{ml}$ of venous blood sample was collected for estimation of serum albumin, total protein, cholesterol, creatinine, blood urea, and blood count including hemoglobin and ESR. Cut off value of low serum albumin was $<2.5 \mathrm{gm} / \mathrm{dl}$, low $\mathrm{STP}<6.00 \mathrm{gm} / \mathrm{dl}$, high cholesterol $>250$ $\mathrm{mg} / \mathrm{dl}$, high serum creatinine $>0.6 \mathrm{mg} / \mathrm{dl}$ and $\mathrm{UTP}>1 \mathrm{gm} / \mathrm{m}^{2} /$ day. Mantoux test (MT) and Bacillus
calmette-Guernie (BCG) acceleration tests were performed when indicated. Antinuclear antibody (ANA) and anti DNA double stranded antibody (anti ds-DNA) were measured by enzyme-linked immunosorbent assay (ELISA) in the children when indicated to rule out systematic disease. HbsAg was tested by screening and ELISA. Chest X-ray and Ultrasonography of the kidneys, ureters and bladder were performed for all the patients. Renal biopsy was done for SRNS patients, NS with atypical presentation and before giving $3^{\text {rd }}$ line drug.

Study Definition: SSNS was defined as responding to steroid therapy within 4 weeks after initiation of the therapy ${ }^{2,3}$. IFRNS was defined as less than 4 relapses within 1 year or less than 2 relapses within 6 months after initial responsive episodes. FRNS was defined as more than 4 relapses in one year and more than 2 relapses within 6 months after initial responsive episode. Remission was defined as protein free urine for 3 consecutive days and relapse was defined as proteinuria (urine albumin $3+$ or more) for three consecutive days after responsive episode ${ }^{2,3}$. The occurrence of 2 consecutive relapses during alternate day prednisolone therapy or within 2 weeks of its discontinuation was defined as SDNS ${ }^{2,3}$. No remission after 4 weeks of standard prednisolone the therapy at 60 $\mathrm{mg} / \mathrm{m}^{2} /$ day was defined as SRNS ${ }^{2,3}$.

Statistical analysis: Statistical analysis was performed by using SPSS. ANOVA was used to compare the difference in means. Chi square test was used to compare between the groups.

\section{Results}

Table 1 shows means ( \pm SD) of serum total protein (STP). The mean $( \pm \mathrm{SD})$ serum total protein was significantly low in SRNS than both groups of SSNS $(\mathrm{P}<0.01$ and $<0.001)$. Higher difference was observed between SRNS and IFRNS $(\mathrm{P}<0.001)$. However the difference between FRNS+SDNS and IFRNS was not statistically significant. ANOVA Test.

Table 1: Comparison of serum total protein (STP) of steroid resistant and steroid sensitive groups

\begin{tabular}{|c|c|c|c|c|c|c|}
\hline \multirow[b]{2}{*}{$\begin{array}{l}\text { Parameters } \\
\text { STP }(g / d l)\end{array}$} & \multirow[b]{2}{*}{ No(n) } & \multirow[b]{2}{*}{ Mean \pm SD } & \multirow[b]{2}{*}{ Range } & \multicolumn{2}{|c|}{$95 \% \mathrm{CI}$} & \multirow[b]{2}{*}{$P$ value } \\
\hline & & & & $\begin{array}{l}\text { Lower } \\
\text { bound }\end{array}$ & $\begin{array}{l}\text { Upper } \\
\text { bound }\end{array}$ & \\
\hline SRNS (B) & 19 & $3.22 \pm 0.86$ & $1.80-5.40$ & 2.81 & 3.93 & B Vs $A_{1}<0.01 * *$ \\
\hline $\begin{array}{l}\text { FRNS+SDNS } \\
\left(\mathrm{A}_{1}\right)\end{array}$ & 11 & $4.18 \pm 0.57$ & $3.50-5.10$ & 3.80 & 4.57 & B Vs $A_{2}<0.001 * * *$ \\
\hline IFRNS $\left(\mathrm{A}_{2}\right)$ & 13 & $4.58 \pm 0.85$ & $3.30-6.00$ & 4.07 & 5.09 & $\mathrm{~A}_{1} \mathrm{Vs} \mathrm{A}_{2}>0.10^{\mathrm{ns}}$ \\
\hline
\end{tabular}

Group Identification: Group B: Steroid resistant; Group A1: FRNS+SDNS (steroid sensitive); Group A2: IFRNS (steroid sensitive)

Table 2 shows the mean $( \pm \mathrm{SD})$ of serum albumin levels were significantly lower in SRNS than FRNS+SDNS and IFRNS group $(\mathrm{P}<0.01)$. There was no difference between FRNS+SDNS and IFRNS. Anova Test. 
Table 2: Comparison of serum albumin (g/dl) parameters of steroid resistant and steroid sensitive groups

\begin{tabular}{|c|c|c|c|c|c|c|}
\hline \multirow{2}{*}{$\begin{array}{l}\text { Parameters } \\
\text { serum albumin } \\
(\mathrm{g} / \mathrm{dl})\end{array}$} & \multirow[t]{2}{*}{ No(n) } & \multirow[t]{2}{*}{ Mean \pm SD } & \multirow[t]{2}{*}{ Range } & \multicolumn{2}{|c|}{$95 \%$ CI } & \multirow[t]{2}{*}{ P value } \\
\hline & & & & $\begin{array}{l}\text { Lower } \\
\text { bound }\end{array}$ & $\begin{array}{l}\text { Upper } \\
\text { bound }\end{array}$ & \\
\hline SRNS (B) & 19 & $1.24 \pm 0.40$ & $0.80-2.10$ & 1.04 & 1.44 & B Vs $A_{1}<0.01 * *$ \\
\hline FRNS+SDNS $\left(\mathrm{Al}_{1}\right)$ & 11 & $1.76 \pm 0.35$ & $1.00-2.10$ & 1.53 & 2.00 & B Vs $\mathrm{A}_{2}<0.001 * * *$ \\
\hline IFRNS $\left(\mathrm{A}_{2}\right)$ & 13 & $1.81 \pm 0.45$ & $0.80-2.40$ & 1.53 & 2.08 & $\mathrm{~A}_{1} \mathrm{Vs} \mathrm{A}_{2}>0.10^{\mathrm{ns}}$ \\
\hline
\end{tabular}

Table 3 shows serum cholesterol was higher in SRNS and FRNS+SDNS compared to IFRNS $(\mathrm{P}<0.001,<0.01)$. It did not differ between SRNS and FRNS+SDNS. ANOVA Test.

Table 3: Comparison of serum cholesterol (mg\%) parameters of steroid resistant and steroid sensitive groups

\begin{tabular}{|c|c|c|c|c|c|c|}
\hline \multirow{2}{*}{$\begin{array}{l}\text { Parameters } \\
\text { Serum cholesterol } \\
(\mathrm{mg} \%)\end{array}$} & \multirow[t]{2}{*}{ No(n) } & \multirow[t]{2}{*}{ Mean \pm SD } & \multirow[t]{2}{*}{ Range } & \multicolumn{2}{|c|}{$95 \%$ CI } & \multirow[t]{2}{*}{ P value } \\
\hline & & & & $\begin{array}{l}\text { Lower } \\
\text { bound }\end{array}$ & $\begin{array}{l}\text { Upper } \\
\text { bound }\end{array}$ & \\
\hline SRNS (B) & 19 & $503.50 \pm 58.33$ & $360-648$ & 475.36 & & $\mathrm{~B}$ Vs $\mathrm{A}_{1}>0.05^{\mathrm{ns}}$ \\
\hline FRNS+SDNS $\left(A_{1}\right)$ & 11 & $430.50 \pm 83.10$ & $305-619$ & 374.63 & & B Vs $\mathrm{A}_{2}<0.001 * * *$ \\
\hline $\operatorname{IFRNS}\left(\mathrm{A}_{2}\right)$ & 13 & $304.50 \pm 0.16$ & $200-485$ & 256.10 & & $\mathrm{~A}_{1} \mathrm{Vs}_{2}<0.01^{* *}$ \\
\hline
\end{tabular}

Table 4 shows serum creatinine mean $( \pm \mathrm{SD})$ was higher in SRNS than FRNS+SDNS $(\mathrm{P}<0.001)$ and IFRNS $(\mathrm{P}<0.001)$. No difference was observed between subgroup of SSNS.

Table 4: Comparison of serum creatinine ( $\mathrm{mg} \%)$ parameters of steroid resistant and steroid sensitive groups

\begin{tabular}{|c|c|c|c|c|c|c|}
\hline \multirow[b]{2}{*}{$\begin{array}{l}\text { Parameters } \\
\text { Serum } \\
\text { creatinine } \\
(\mathrm{mg} \%)\end{array}$} & \multirow[b]{2}{*}{ No (n) } & \multirow[b]{2}{*}{$\begin{array}{c}\text { Mean } \pm \\
\text { SD }\end{array}$} & \multirow[b]{2}{*}{ Range } & \multicolumn{2}{|c|}{$95 \%$ CI } & \multirow[b]{2}{*}{$P$ value } \\
\hline & & & & $\begin{array}{l}\text { Lower } \\
\text { bound }\end{array}$ & $\begin{array}{l}\text { Upper } \\
\text { bound }\end{array}$ & \\
\hline SRNS (B) & 19 & $1.05 \pm 0.32$ & $0.60-0.80$ & 0.60 & 1.70 & $\mathrm{~B} \mathrm{Vs} \mathrm{A}_{1}<0.001 * * *$ \\
\hline FRNS+SDNS ( $\left.\mathrm{Al}_{1}\right)$ & 11 & $0.66 \pm 0.07$ & $0.60-0.80$ & 0.60 & 0.80 & B Vs $\mathrm{A}_{2}<0.001 * * *$ \\
\hline IFRNS $\left(\mathrm{A}_{2}\right)$ & 13 & $0.65 \pm 0.00$ & $0.60-0.80$ & 0.60 & 0.71 & $\mathrm{~A}_{1} \mathrm{Vs} \mathrm{A}_{2}>0.50^{\mathrm{ns}}$ \\
\hline
\end{tabular}

Table 5 urinary total protein (UTP) was higher in SRNS than FRNS+SDNS and IFRNS $(\mathrm{P}<0.001)$. The difference between $\mathrm{SRNS}+\mathrm{SDNS}$ and IFRNS was also significant $(\mathrm{P}<0.05)$.

Table 5: Comparison of urinary total protein (g/dl) of steroid resistant and steroid sensitive groups

\begin{tabular}{|c|c|c|c|c|c|c|}
\hline \multirow{2}{*}{$\begin{array}{l}\text { Parameters } \\
\text { Urinary total } \\
\text { protein }(\mathrm{g} / \mathrm{dl})\end{array}$} & \multirow[t]{2}{*}{ No(n) } & \multirow[t]{2}{*}{ Mean \pm SD } & \multirow[t]{2}{*}{ Range } & \multicolumn{2}{|c|}{$95 \% \mathrm{CI}$} & \multirow[t]{2}{*}{ P value } \\
\hline & & & & $\begin{array}{l}\text { Lower } \\
\text { bound }\end{array}$ & $\begin{array}{l}\text { Upper } \\
\text { bound }\end{array}$ & \\
\hline SRNS (B) & 19 & $5.78 \pm 1.68$ & $2.73-9.38$ & 4.96 & 6.60 & B Vs $A_{1}<0.001 * * *$ \\
\hline FRNS+SDNS $\left(\mathrm{Al}_{1}\right)$ & ) 11 & $3.63 \pm 0.85$ & $2.10-5.55$ & 3.06 & 4.21 & B Vs $\mathrm{A}_{2}<0.001 * * *$ \\
\hline $\operatorname{IFRNS}\left(\mathrm{A}_{2}\right)$ & 13 & $2.80 \pm 1.12$ & $1.50-5.22$ & 2.12 & 3.48 & $\mathrm{~A}_{1} \mathrm{Vs} \mathrm{A}_{2}>0.05^{*}$ \\
\hline
\end{tabular}

Table 6 shows that no difference was observed between SRNS and FRNS+SDNS. The mean $( \pm$ SD) hemoglobin in SRNS and FRNS+SDNS were lower than IFRNS $(\mathrm{P}<0.01$ and $<0.05)$.

Table 6: Comparison of hemoglobin (\%) of steroid resistant and steroid sensitive groups

\begin{tabular}{|c|c|c|c|c|c|c|}
\hline \multirow[b]{2}{*}{$\begin{array}{l}\text { Parameters } \\
\text { Hemoglobin (\%) }\end{array}$} & \multirow[b]{2}{*}{ No(n) } & \multirow[b]{2}{*}{$\begin{array}{l}\text { Mean } \pm \\
\text { SD }\end{array}$} & \multirow[b]{2}{*}{ Range } & \multicolumn{2}{|c|}{$95 \% \mathrm{CI}$} & \multirow[b]{2}{*}{$P$ value } \\
\hline & & & & $\begin{array}{l}\text { Lower } \\
\text { bound }\end{array}$ & $\begin{array}{l}\text { Upper } \\
\text { bound }\end{array}$ & \\
\hline SRNS (B) & 19 & $9.63 \pm 1.95$ & $6.36-14.50$ & 8.69 & 10.57 & B Vs $A_{1}<0.10^{\text {ns }}$ \\
\hline FRNS+SDNS $\left(\mathrm{A}_{1}\right)$ & 1) 11 & $10.84 \pm 1.33$ & $8.70-13.00$ & 9.95 & 11.73 & B Vs $\mathrm{A}_{2}<0.01^{* *}$ \\
\hline $\operatorname{IFRNS}\left(\mathrm{A}_{2}\right)$ & 13 & $12.45 \pm 2.21$ & $8.30-15.00$ & 11.1 & 13.78 & $\mathrm{~A}_{1} \mathrm{Vs}_{2}>0.05^{*}$ \\
\hline
\end{tabular}

\section{Discussion}

Ninety five percent nephrotic syndromes are idiopathic (INS) and $80 \%$ of idiopathic childhood nephrotic syndromes are MCNS. Presence of hypertension, gross hematuria and impaired renal function indicate significant glomerular lesion ${ }^{9,11}$.

In this study, significantly low serum total protein, low albumin, high urinary total protein, high cholesterol, urinary total protein and low hemoglobin were noted in SRNS compared to SSNS. Also significantly high cholesterol and low hemoglobin were noted in this study group of FRNS+SDNS compared to IFRNS. These findings are in corollary with standard text books ${ }^{2,8,12}$. Low serum total protein and albumin can be due to long standing proteinuria which was either due to the disease as in SRNS type or late treatment ${ }^{2,10}$. Very high cholesterol and low hemoglobin usually mean non minimal lesion $\mathrm{NS}^{2,10}$. However volume contraction can give rise to high hemoglobin and high hematocrit level ${ }^{10}$. Raised serum creatinine in SRNS, FRNS+SDNS groups in this study was consistent with previous studies ${ }^{2,10}$. Tarashish et $\mathrm{al}^{13}$ observed end stage renal disease in $5 \%$ and $20 \%$ of SSNS and SRNS respectively, similar type of finding with raised serum creatinine in this study was positively correlated with poor outcome.

Gulati et $\mathrm{al}^{14}$ had seen no significant differences among various subgroups which biochemical parameters like blood urea nitrogen, serum creatinine, serum total protein, albumin, and cholesterol were compared. Their observation as poor response was associated with age of onset more than 8 years, male sex, hypertension, microscopic hematuria and presence of non-minimal nephrotic syndrome lesions on histopathology.

Srivastava $^{15}$ observed proteinuria with associated microscopic hematuria were more likely a manifestation of significant renal lesion. Constantinescu and Mendoza ${ }^{16}$ observed poor association with hematuria. MCNS has occasional gross hematuria $^{17}$ and transient hypertension ${ }^{18}$.

Begum $^{19}$ observed hypertension, hematuria and renal impairment significantly higher in SRNS. Singh et $\mathrm{al}^{20}$ found hematuria heavy proteinuria, azotemia and hypertension in idiopathic focal segmental glomerulosclerosis. Other studies also has seen different prognostic markers. Caridi et $\mathrm{al}^{21}$ found no different in outcome of NS in patients with single mutation of nephrin and podocin genes. Ezrin-a cytoskelaton linking protein a patent maker of podocyte injury has been low in nephrotic syndrome with unfavorable prognosis ${ }^{22}$. Misra et $\mathrm{al}^{23}$ and Roy et $\mathrm{al}^{24}$ has seen decreased serum IgG level as predictive marker for unfavorable prognosis of nephrotic syndrome in children.

\section{Conclusion}

Steroid resistant nephritic syndrome (SRNS) had low serum total protein (STP), albumin and hemoglobin compared to steroid sensitive nephrotic syndrome (SSNS). Steroid resistant nephrotic syndrome also had high cholesterol, creatinine and urinary total protein (UTP) than 
steroid sensitive nephrotic syndrome. FRNS+SDNS had high cholesterol, UTP and low hemoglobin than IFRNS. So low serum total protein (STP), albumin, hemoglobin and high cholesterol, creatinine, urinary total protein (UTP) are prognostic features in children with idiopathic nephrotic syndrome. Further large scale, multicenter study would be helpful.

\section{Reference}

1. ISKDC (International Study of Kidney Disease in Children), Nephrotic Syndrome in Children: Prediction of histopathology from clinical and laboratory characteristics at the time of diagnosis. Kidney Int. 1978; 13:159-165.

2. Srivastava RN, Bagga A. Nephrotic Syndrome. In Srivastava RN, Bagga A, edn. Pediatric nephrology, 5th ed, New Delhi: Jaypee Brothers, Medical Publishers (P) Ltd, 2011; 195-234

3. Abdur Rahman MD, Aikhonbare HA, Babaoye FA, Sathiakumar N, Narayana PT. Clinicopathological features of childhood Nephrotic Syndrome in Northern Nigeria. QJ Med 1990; 75: 563-576

4. Eddy AA, Symons JM, Nephrotic Syndrome in childhood. Lancet 2003; 362:629-639

5. Mc Kinney PA, Feltbower RG, Brocklebank JT, Fitzpatrick MM. time trends and ethnic patterns of childhood Nephrotic Syndrome in Yorkshire, UK. Pediatric Nephrology 2001; 16:1040-1044

6. Churg S, Habib R, White RH. Pathology of Nephrotic Syndrome in children. A report for the international study of kidney disease in children. Lancet 1970; 1: 1299-1302

7. Salcedo JR, Thabet MA, Latta K, Chan JC. Nephrosis in childhood. Nephron 1995; 71:375-385

8. Pais P, Avner ED. Nephrotic Syndrome: Nelson Textbook of Pediatrics, edited by Klingman RM, Stanton BF, Schoa NF, Geme III JWS, Behrman RE, 19th ed. Philadelphia: Elsevier Sauders, 2011: 1801-1807
9. ISKDC (International Study of Kidney Disease in Children), The Primary Nephrotic Syndrome in children. Identification of patients with minimal change Nephrotic Syndrome from initial response to prednisolone. A report of the international study of kidney disease of children. J Pediatric 1981; 98: 561-564

10. Mortazavi F, Majidi J. Evaluation of hemostatic factors in children with nephritic syndrome. Pak J of Med Sci 2008; 24(3): 356-9

11. Gulati S, Kher V, Sharma RK, Gupta A. Steroid response pattern in Indian children with nephrotic syndrome. Acta Paediatr 1994; 83(5): 530-3

12. Niaudet $P$, Boyer O. idiopathic Nephrotic Syndrome in children: clinical aspects. In Pediatric Nephrology. 6th edition, edited by Avner ED, Harmon WE, Niaudet P, Yoskikawa N, Springer-Verlog Berlin Heidelberg 2009; 667-702

13. Tarshish P, Tobin JN, Bernstein J. Prognostic significance of the early course of minimal change nephrotic syndrome: report of the International Study of Kidney Disease in Children. J Am Soc Neohrol. May 1997;8(5): 769-76

14. Gulati S, Sharma A, Sharma R. et al Do current recommendations for kidney biopsy in nephrotic syndrome need modifications? Pediatr Nephrol 2002; 17:404-408

15. Srivastava T, Garola RE, Whiting JM, et al. Synaptopodin expression in idiopathic nephrotic syndrome of childhood. Kidney Int 2001; 15: 118-125

16. Constantinescu AR, Shah HB, Foote EF, Weiss LS. Predicting first year relapses in children with nephrotic syndrome. Pediatrics 2000: 105:492-5

17. Mendoza SA, Reznik VM, Griswold WR, Krensky AM, Yorgin PD, Tune BM. Treatment of steroid-resistant focal segmental glomerulosclerosis with pulse methylprednisolone and alkylating agents. Pediatr Nephrol. Jul 1990; 4(4): 307-7 18. Ghedira Besbes L, mallek A, Huediche MN. Idiopathic nephrotic syndrome in children: report of 57 cases. Tunis Med 2003 Sep; 81(9): 702-8

19. Begum A, Rahman H, Hossain MM, Sultana S, Jahan S, Muinuddin G. Histological variant of Nephrotic Syndrome with a typical presentation in children. Mymensingh Med J; 2009: 18(1): 43-46

20. Ten years follow-up of idiopathic focal and segmental glomerulosclerosis. Saud J of Kidney Diseases and Trans 1994 Sep; 5(3): 354-358

Caridi G, Gigante M, Ravani P et al. clinical Features and Long-Term Outcome of Nephrotic Syndrome Associated with Heterozygous NPHS1 and NPHS2 M 